Polish Journal of Microbiology

2011, Vol. 60, No 2, 133-138

ORGINAL PAPER

\title{
$\beta$-glucanase Productivity Improvement via Cell Immobilization of Recombinant Escherichia coli Cells in Different Matrices
}

\author{
USAMA BESHAY ${ }^{1, *}$, HESHAM EL-ENSHASY ${ }^{1}$, I.M.K. ISMAIL ${ }^{2}$, HASSAN MOAWAD \\ and SAWSAN ABD-EL-GHANY \\ ${ }^{1}$ Bioprocess Development Department, Genetic Engineering and Biotechnology Research Institute (GEBRI) \\ Mubarak City for Scientific Research and Technology Applications, New Bourg El-Arab City \\ Universities and Research District, 21934 Alexandria, Egypt \\ ${ }^{2}$ Botany Department, Faculty of Science, Cairo University, Cairo, Egypt \\ ${ }^{3}$ Agricultural Microbiology Department, National Research Centre, Dokki, Cairo, Egypt
}

Received 10 September 2010, revised 3 March 2011, accepted 10 March 2011

Abstract

The studies have been performed to analyze the production of $\beta$-glucanase by a recombinant strain of Escherichia coli immobilized in different matrices. Porous sintered glass SIRAN ${ }^{\oplus}$, Ceramic supporting matrices and Broken Pumice stone as well as SIRAN Raschig-rings were examined for the immobilization of whole bacterial cells. The $\beta$-glucanase activity of bacteria immobilized in CeramTec PST 5 (4-5 mm) was very low. CeramTec PST $5(1.5-2.5 \mathrm{~mm})$ was found to be the best carrier compared to all other matrices regarding glucanase production $(630 \mathrm{U} / \mathrm{ml})$ and compared to enzyme activity produced by free cells $(500 \mathrm{U} / \mathrm{ml})$. Different doses of matrices were applied $(2,5,7,10 \mathrm{~g} / \mathrm{lask})$ in the form of "matrix weight". Using 2 g/flask of CeramTec PST $5(1.5-2.5 \mathrm{~mm})$ yielded enzyme activity of $630 \mathrm{U} / \mathrm{ml})$. CeramTec gives highest operational stability of $\beta$-glucanase by repeated batch fermentation to 5 cycles, and activity reached $660 \mathrm{U} / \mathrm{ml}$. Scanning electron microscopy observations showed a high number of vegetative cells that continued growth inside the matrices, indicating that $\beta$-glucanase activity improvement was due to the immobilization of the cells.

Ke y words: $\beta$-glucanase, organic and/or inorganic matrices, cell immobilization, scanning electron microscope

\section{Introduction}

$\beta$-1,3-glucanase, synthesized by many bacteria, hydrolyzes glucan polymers containing $\beta$-1,3-linkages (Kourkoutas et al., 2004). This enzyme plays a key role in both the pulp drainability and beatability changes. The use of pure endoglucanase was responsible for most of the success in deinking (Gusek et al., 1991). Enzymes displaying $\beta$-glucanase activity have been found to have a variety of uses. For example they are used as a biological control of soil-borne plant pathogens and as a food supplementation (Weuster-Botz, 1993). $\beta$-1,3-glucanase is an important enzyme in the field of industrial and agricultural processing. The resistance of this enzyme to denaturation by high temperature and $\mathrm{pH}$ extremes makes it particularly important.

Cell immobilization can be defined as the confinement or localization of viable microbial cells to a certain defined region (Hamdy et al., 1990). This is achieved by significantly increasing the effective size or density of the cells by their aggregation or by attachment of the cells to some support surface. Thus, flocculated cells in the form of large aggregates are considered to be immobilized. The advantages of inorganic supports compared to organic supports were studied by several groups (Kourkoutas et al., 2004). These include their abundance and low price, higher mechanical strength, high thermal stability, higher resistance to organic solvents and microbial attack, easy handling and easy regenerability (Gusek et al., 1991; Weuster-Botz, 1993). Many inorganic supports were studied for immobilization such as polygorskite, montmorilanite, hydromica, porous porcelain, pumice stone and glass beads (Colagrande et al., 1994; Beshay, 1998).

The aim of the present work wasto optimize the production of $\beta$-glucanases using a high bacterial cell density cultivation strategy. Cell immobilization is applied to improve the productivity of the recombinant strain. Different inorganic supports such as porous sintered glass SIRAN ${ }^{\circledR}$ SIKUG 041, Ceramic supporting matrices and Broken Pumice stone as well as SIRAN Raschigrings were tested.

* Corresponding author: U. Beshay, Mubarak City for Scientific Research and Technology Applications, Bioprocess Development Department, New Bourg El-Arab City, Universities and Research District; 21934 Alexandria, Egypt; phone: +2 034593422 ; fax: +2 034593 407; e-mail: ube@fermtech.techfak.uni-bielefeld.de; u.beshay@mucsat,sci.eg 


\section{Experimental}

Material and Methods

Microorganism. The E. coli strain BL21(DE3) pET-bglhisactophilin-Sec used in this work was kindly provided by prof. dr Erwin Flaschel, the head of the Fermentation Engineering Department, Bielefeld University, Germany. This strain contained a plasmid coexpressing protein of a chimeric Bacillus amyloliquefaciens $\beta$-glucanase $C$-terminally linked with hisactophilin from Dictyostelium discoideum as metal chelating affinity tag and kill protein from the plasmid CoIE1 as a permeabilizing agent for the outer membrane of Escherichia coli. The fusion protein was expressed under control of the genuine promoter of $\beta$-glucanase from Bacillus amyloliquefaciens, whereas the kill protein was under the control of stationary phase promoter of the fic gene (Miksch et al., 1997; Flaschel et al., 1998).

Media for vegetative cell growth and fermentation. The optimized medium Terrific broth glycerol TBG (Beshay et al., 2003) used in this work contained the following gm per liter: 12.0 peptone, 24.0 yeast extract, $5.0 \mathrm{NaCl}, 7.0$ lactose. These components were dissolved in $800 \mathrm{ml}$ distilled water and $\mathrm{pH}$ was adjusted at 7.0. The medium was distributed into flasks containing $40 \mathrm{ml}$ medium each and then autoclaved at $121^{\circ} \mathrm{C}$ for 20 minutes. Kanamycin was added after cooling $(50 \mu \mathrm{l} / 50 \mathrm{ml})$. The second part of the medium, i.e. "salts", consisted of g per liter: 2.30 potassium dihydrogen phosphate, 12.50 di-potassium hydrogen phosphate. Salts were dissolved separately in $200 \mathrm{ml}$ distilled water and distributed into 20 test tubes each containing $10 \mathrm{ml}$, then autoclaved. Sterilized salts were added to the basal medium before inoculation.

Porous supports for immobilization of E. coli. Three inorganic porous supports, porous sintered glass SIRAN, broken pumice stone, and the ceramic catalyst carrier CeramTec F1/porous PST 5 were used to immobilize the cells. The first supporting matrix used to immobilize E. coli was SIRAN ${ }^{\circledR}$ in the form of porous sintered glass beads (Schott Engineering GmbH, Mainz, Germany). Two different shapes of porous sintered glass SIRAN ${ }^{\circledR}$ beads and Raschig-rings SIRAS 09 were used in this study. The characteristics of porous sintered glass SIRAN are gathered in Table I.

Table I

Characteristics of porous sintered glass (SIRAN ${ }^{\circledR}$ )

\begin{tabular}{|l|c|c|c|c|}
\hline $\begin{array}{c}\text { Carrier } \\
\text { type }\end{array}$ & $\begin{array}{c}\text { Characteristic } \\
\text { dimensions } \\
(\mathrm{mm})\end{array}$ & $\begin{array}{c}\text { Pore } \\
\text { volume } \\
(\%)\end{array}$ & $\begin{array}{c}\text { Pore } \\
\text { diameter } \\
(\mu \mathrm{m})\end{array}$ & $\begin{array}{c}\text { Surface } \\
\text { area } \\
\mathrm{m}^{2} / \mathrm{g}\end{array}$ \\
\hline SIKUG 041 & $0.4-1$ & $55-60$ & $<120$ & 0.15 \\
\hline SIRAS 09 & $8.8 \times 9$ & 70 & $1.6-400$ & 0.4 \\
\hline
\end{tabular}

The broken pumice stone was supplied by Joseph Raab GmbH \& Cie. KG (Neuwied, Germany). It had a diameter of $1.5-2.5 \mathrm{~mm}$, a pore volume of $0.93 \mathrm{ml} / \mathrm{g}$, a particle density of $670 \mathrm{~g} / \mathrm{l}$ and a specific surface area of $27 \mathrm{~cm}^{2} / \mathrm{cm}^{3}$. The chemical composition of broken pumice stone is as follows: silicic acid $\mathrm{SiO}_{2} 55 \%$, aluminum oxide $\mathrm{Al}_{2} \mathrm{O}_{3} 22 \%$, alkalis $\mathrm{K}_{2} \mathrm{O}+\mathrm{Na}_{2} \mathrm{O} 12 \%$, iron oxide $\mathrm{Fe}_{2} \mathrm{O}_{3} 3 \%$, calcium oxide $\mathrm{CaO} 2 \%$, magnesium oxide $\mathrm{MgO}$ 1\%, titanium dioxide $\mathrm{TiO}_{2}$ 0.5\%. Ignition loss was $4 \%$.

The CeramTec ${ }^{\circledast}$ carrier F1/porous PST 5 was obtained from CeramTec ${ }^{\circledast}$ AG (Innovative Ceramic Engineering, Wunsiedel, Germany). Two different particle sizes were used, $1.5-2.5 \mathrm{~mm}$ and $4-5 \mathrm{~mm}$. It has a particle density of $1430 \mathrm{~g} / \mathrm{l}$, a pore volume of $0.25 \mathrm{ml} / \mathrm{g}$ and a specific surface area of $20 \mathrm{~cm}^{2} / \mathrm{cm}^{3}$.

Before use, the supports were cleaned in $10 \%$ aqueous hydrogen peroxide solution by gentle agitation at $80^{\circ} \mathrm{C}$ for $30 \mathrm{~min}$. After the liquid was decanted, the beads were washed with water and dried overnight at $110^{\circ} \mathrm{C}$.

\section{Cultivation of $E$. coli in immobilized form}

Effect of using different inorganic matrices on $\boldsymbol{\beta}$-glucanase production. Batch cultivation was carried out in Erlenmeyer flasks $(250 \mathrm{ml})$, each containing $50 \mathrm{ml}$ of TBG-medium. The flasks were inoculated with $2.5 \mathrm{ml}(\mathrm{OD} 600=4)$ fresh bacterial cells grown for $24 \mathrm{~h}$. To each flask, $2 \mathrm{~g}$ of pre-sterilized supporting materials such as, porous sintered glass beads SIRAN SIKUG 041, CeramTec PST 5 (1.5-2.5 mm and 4-5 mm), Broken Pumice stone (1.5-2.5 mm) and Porous sintered glass Raschig-rings SIRAS 09 were added in order to select the most suitable matrix for maximal production of $\beta$-glucanase. The flasks were incubated in a shaker incubator $(200 \mathrm{rpm})$ at $37^{\circ} \mathrm{C}$ for $72 \mathrm{~h}$. As a control, a freecell suspension was cultivated under the same culture conditions. Samples of the liquid culture were taken at indicated intervals for the determination of $\beta$-glucanase activity and free cell concentration. In addition, carrier samples were taken for the determination of immobilized cells and in some cases for scanning electron microscope (SEM) observations.

Effect of using different doses of inorganic matrices on $\boldsymbol{\beta}$-glucanase production. Different quantities of selected matrices were tested to find out the most suitable one. The quantities were $(2,5,7$ and 10) g per flask containing $50 \mathrm{ml}$ culture medium. Samples were taken during the experimental runs to determine cell growth and enzyme activity.

Repeated batch cultivations of $E$. coli on inorganic matrices. For establishing the long-term stability of $\beta$-glucanase production by immobilized cells, repeated batch cultivations were carried out. Every $48 \mathrm{~h}$ the biocatalysts were washed several times with sterile water and transferred into fresh production medium under 
repeated batch cultivation conditions. This process was carried out by decanting the spent medium every $48 \mathrm{~h}$ and replacing it with fresh medium after washing the matrix with sterile saline. On the other hand, a similar experiment was carried out with free cells to compare the efficiency of free and immobilized cells for the production of glucanase enzyme under these conditions. Samples were taken after each cycle $(48 \mathrm{~h})$ to determine cell density and $\beta$-glucanase activity.

Sample analysis. All determinations reported here were performed in triplicate and the experiments at least in duplicate. The results given are mean values.

The cell density in the medium was monitored by measuring the absorbance at $600 \mathrm{~nm}$ using a spectrophotometer (Pharmacia Biotech). Optical densities values were converted to cell dry weight according to a standard calibration curve previously obtained for E. coli cells. Optical density at $600 \mathrm{~nm}=1$ is equal to $0.4 \mathrm{~g} / \mathrm{l}$ cell dry weight.

The cell density of immobilized cells was determined indirectly by measuring the total amount of protein of the immobilized cells by a method described by (Henry and Clim, 1964). For the determination of the cell density of the immobilized cells, carrier samples were washed with $1 \mathrm{ml}$ phosphate buffer, followed by adding $1 \mathrm{ml}$ lysis buffer and strong vortexing for $5 \mathrm{~min}$ utes at room temperature. The assay test was performed with the supernatant of the lysis solution.

$\beta$-Glucanase activity was determined according to Borriss et al., (1989) using lichenan (Sigma), a polysaccharide from Cetraria islandica as substrate. The activity test described here expresses the activity in units (U) corresponding to the liberation of $1 \mu \mathrm{mol}$ glucose per min at $\mathrm{pH} 5.6$ at $50^{\circ} \mathrm{C}$ from lichenan. Briefly, lichenan solution $(200 \mu \mathrm{l})$ is thermostated at $50^{\circ} \mathrm{C}$ for $5 \mathrm{~min}$ in $1.5 \mathrm{ml}$ reaction vials equipped with plastic covers. A series of reactions was started by adding the sample solution $(20 \mu \mathrm{l})$ at $20 \mathrm{~s}$ intervals. Each reaction was stopped exactly after $20 \mathrm{~min}$ by adding 2-hydroxy3,5-dinitrobenzoic acid (HDNBA) solution (100 $\mu \mathrm{l})$ with intensive mixing. The reaction vials were placed on ice. After cooling, the reaction vials were centrifuged for a few seconds in order to collect the liquid phase. Each cover of the vials was perforated with a needle prior to placing the vials for $10 \mathrm{~min}$ in a boiling water bath followed by rapid cooling in ice water. After cooling, the residual solution in the vials was complemented with distilled water $(1 \mathrm{ml})$. The absorption of this solution was measured at $530 \mathrm{~nm}$.

For morphological studies of E. coli cells in carrier beads, scanning electron microscopy was used. Carrier samples were taken from the flasks, washed twice with phosphate buffer and treated in a laboratory microwave oven according to the method of Giberson et al., 1997. Samples were fixed for 60 seconds in $2.5 \%$ glutaraldehyde (in $50 \mathrm{mM}$ phosphate buffer, $\mathrm{pH} 7.2$ ) at $37^{\circ} \mathrm{C}$. The second fixation was carried out with a solution of $2 \%$ osmium tetraoxide in deionized water for 2.5 minutes at $37^{\circ} \mathrm{C}$. The fixed carriers were dehydrated by treatment with $30,45,60,75$ and $90 \%$ acetone at $40^{\circ} \mathrm{C}$-each step for 5 minutes. At the end of the dehydration process the samples were treated overnight with absolute acetone and dried by the critical point method. The specimens were coated with a thin layer of gold to make the surface more efficient in electron scattering. Finally, the specimens were observed with a JXA-JEOL scanning electron microscope.

\section{Results and Discussion}

\section{Immobilization of $E$. coli cells by adsorption method using inorganic matrices}

Effect of using different matrices on cell growth and $\beta$-glucanase production. As shown in Fig. 1A, freely suspended cells grew and reached maximum CDW of $3.5 \mathrm{~g} / \mathrm{l}$ after $72 \mathrm{~h}$ incubation while biomass concentrations, on Pumice stone and CeramTec $(1.5-2.5 \mathrm{~mm})$ after $72 \mathrm{~h}$, were 3.8 and $3.1 \mathrm{~g} / \mathrm{l}$, respectively.

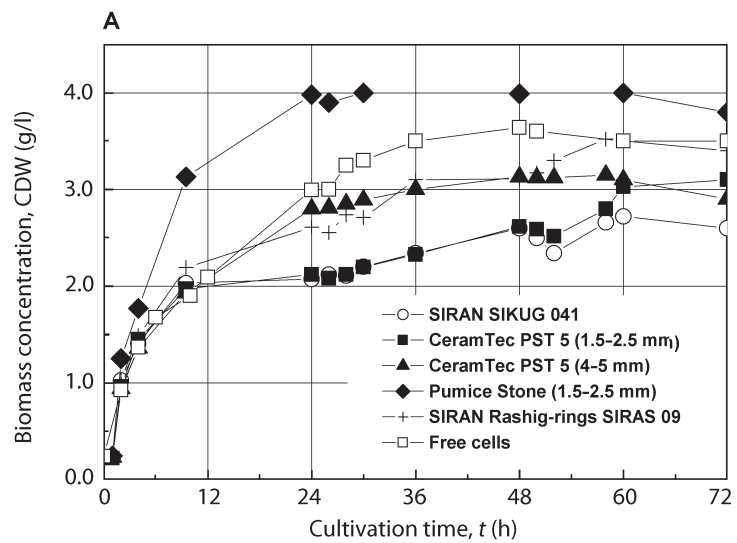

B

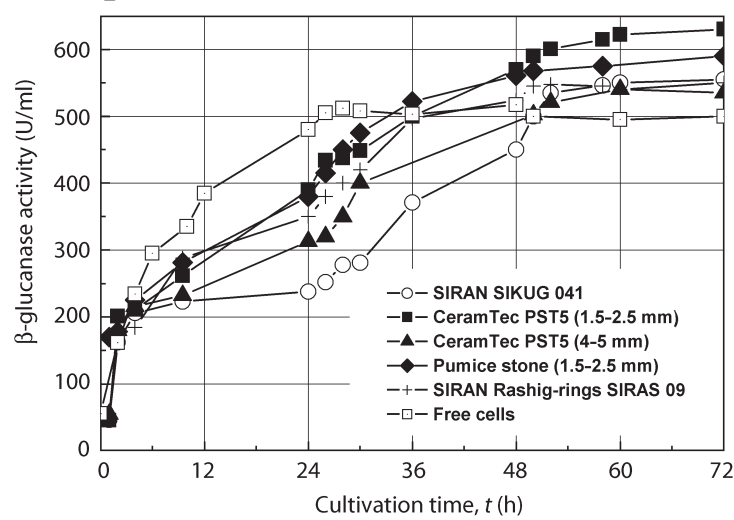

Fig. 1. Effect of different inorganic matrices on cell density (A) and $\beta$-glucanase activity (B) of a recombinant E. coli BL21(DE3) pET-bgl-hisactophilin-Sec strain in immobilized state. 

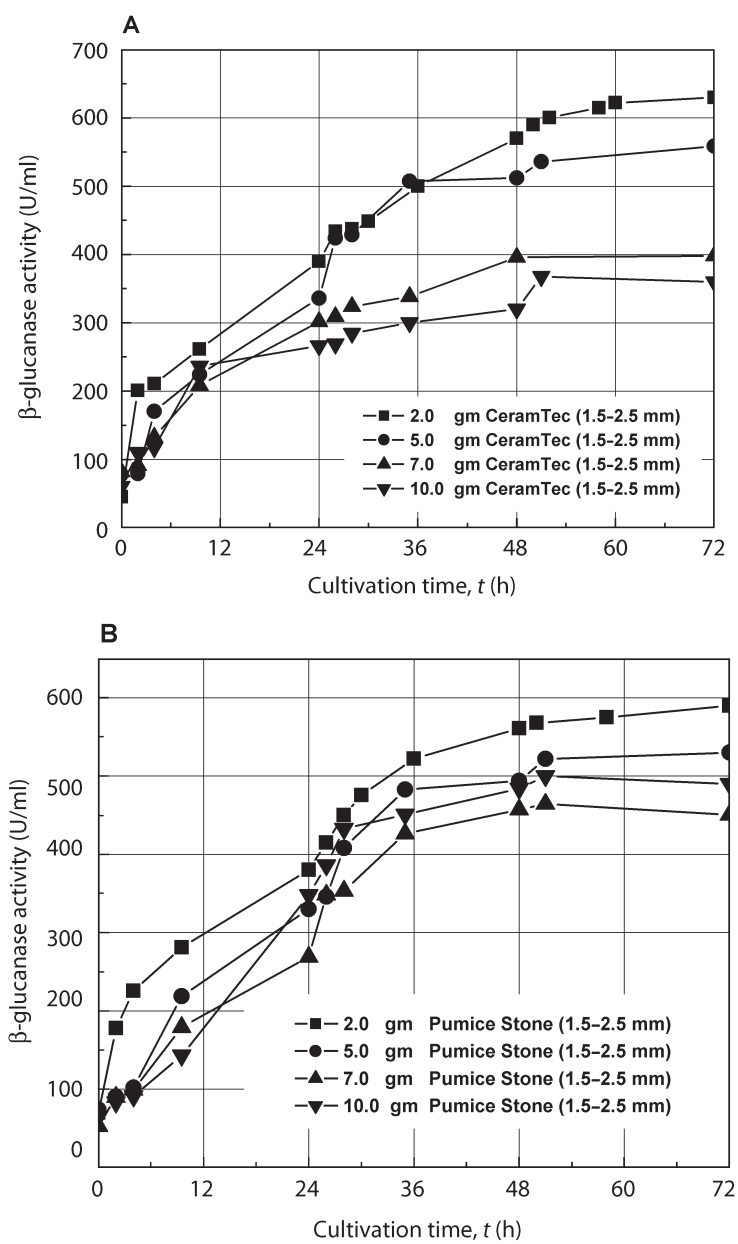

Fig. 2. Effect of CeramTec PST5 (1.5-2.5 mm) (A) and Broken Pumice stone $(1.5-2.5 \mathrm{mmm})$ (B) doses on $\beta$-glucanase production by immobilized E. coli BL21(DE3) pET-bgl-hisactophilin-Sec cells.

$\beta$-glucanase production started to increase markedly after $28 \mathrm{~h}$ and reached a maximum activity of $517 \mathrm{U} / \mathrm{ml}$ at $48 \mathrm{~h}$ for free cells. On the other hand, the results for $\beta$-glucanase production by immobilized cells showed that almost all of the biocatalysts used were more effective enzyme producers than free cells. It was noticed that immobilization bacterial cells on CeramTec PST 5 $(1.5-2.5 \mathrm{~mm})$ and Broken Pumice stone $(1.5-2.5 \mathrm{~mm})$ lead to an increase in $\beta$-glucanase production $(630 \mathrm{U} / \mathrm{ml}$ and $590 \mathrm{U} / \mathrm{ml}$ at $72 \mathrm{~h}$, respectively) in comparison to freely suspended cells $(500 \mathrm{U} / \mathrm{ml})$.

This was probably due to the high amount of cells immobilized inside the matrix during the cultivation process. The difference in enzyme activity among the various matrices could be attributed to the difference in porosity and consequently, oxygen transfers which facilitated better growth of the immobilized cells and higher enzyme production (Fiedurek and Lobarzewski 1990; Beshay and Moreira 2003). Thus, E. coli cells may be immobilized on commercially available porous carriers. Immobilization has been shown to be an adequate means for obtaining high cell densities.

Effect of matrix dose used for cell immobilization on both cell growth and enzyme production by $E$. coli. By comparing different quantities of the matrix for cell immobilization it was found that increasing the amount of carrier weight from 2.0 to $10.0 \mathrm{~g} / 50 \mathrm{ml}$ medium was accompanied by decreasing $\beta$-glucanase production as shown in Fig. 2A, B for CeramTec $(1.5-2.5 \mathrm{~mm})$ and broken Pumice stone (1.5-2.5 $\mathrm{mm})$, respectively.

This could be attributed to the fact that a rise in carrier amount leads to increase in the possible shear stress force and abrasion effect between microbial cells and carrier particles. It was also found that $2.0 \mathrm{~g}$ of CeramTec $(1.5-2.5 \mathrm{~mm})$ is an optimal carrier dose for the highest glucanase production $(630 \mathrm{U} / \mathrm{ml})$ after $72 \mathrm{~h}$ cultivation. However the glucanase activity obtained by immobilized cells in Broken Pumice stone was comparable with that obtained by cell immobilization in CeramTec. This is because of the fact that broken pumice stone shows a tendency to be broken by shaking which leads to a high turbidity in culture medium.

Operational stability of $\beta$-glucanase produced by immobilized cells in CeramTec matrix (1.5-2.5 mm) by the adsorption method. The possibility of the multiple use of E. coli cells immobilized in CeramTec $(1.5-2.5 \mathrm{~mm})$ for $\beta$-glucanase production was studied by repeated batch cultivation for 10 days ( 5 cycles). Each fermentation cycle continued for $48 \mathrm{~h}$ as previously described in materials and methods. The substitution of exhausted (spent) medium with fresh production medium was carried out at the time of maximum enzyme production ( $48 \mathrm{~h}$ for immobilized cells). Figure 3 illustrates also that $\beta$-glucanase production by immobilized cells increased with number of reaction cycles and reached a maximum at the third cycle $(660 \mathrm{U} / \mathrm{ml})$ where $\beta$-glucanase production $(650 \mathrm{U} / \mathrm{ml})$ remained almost stable for the following two batches. On the other hand,

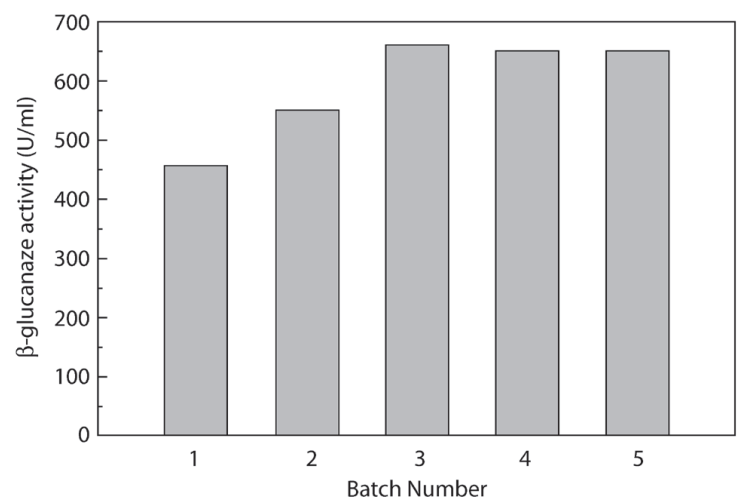

Fig. 3. Repeated batch cultivation of E. coli BL21(DE3) pET-bgl-hisactophilin-Sec strain immobilized in CeramTec PST 5 (1.5-2.5 mm). 


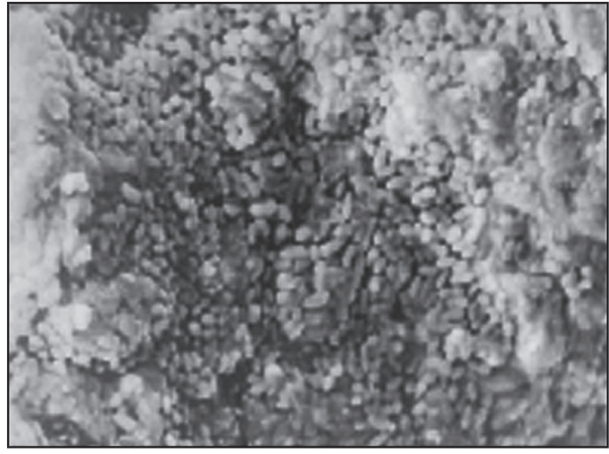

a: $\times 2500$

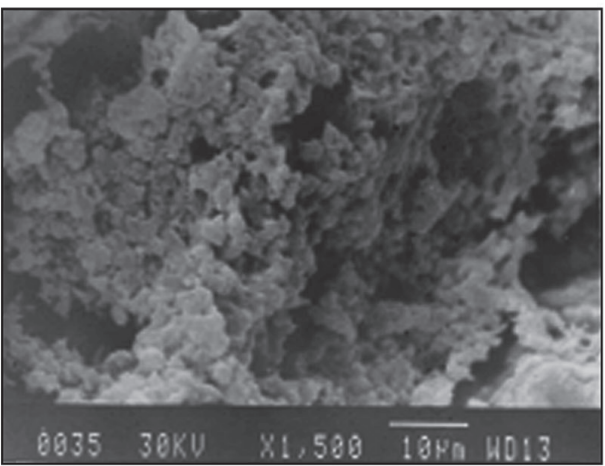

c: $\times 1500$

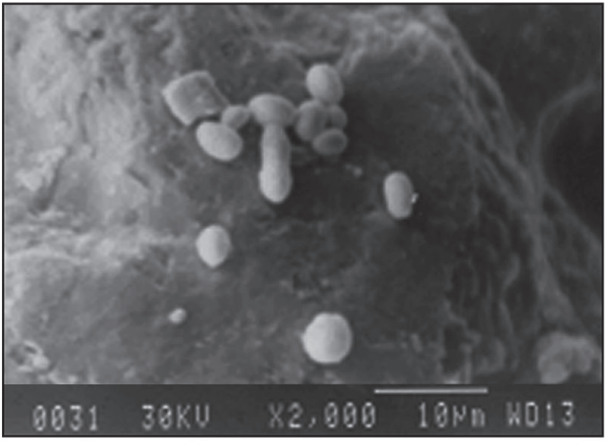

e: $x 2000$

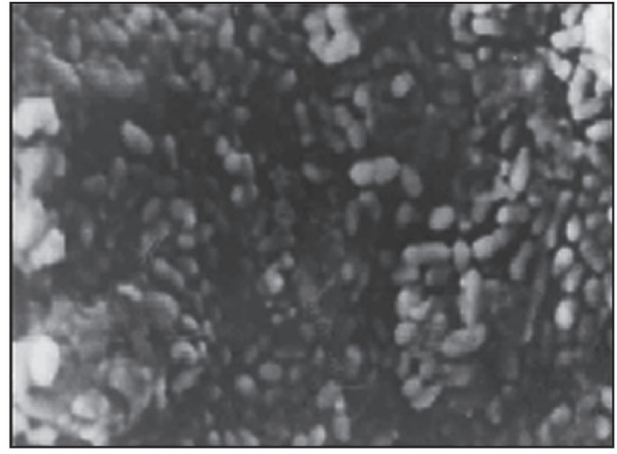

b: $\times 4500$

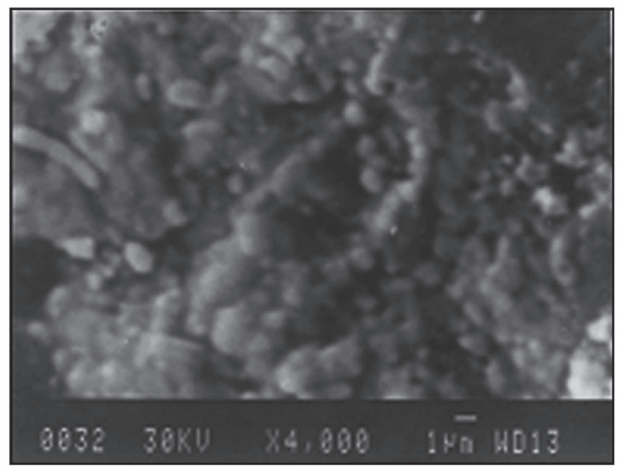

$\mathrm{d}: \mathrm{x} 4000$

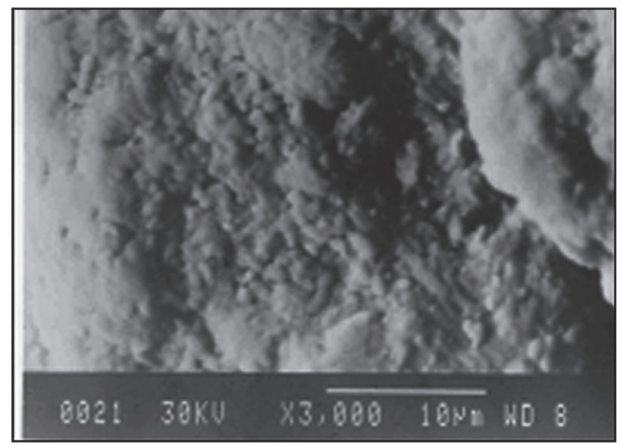

f: 3000

Fig. 4. Scanning electron microscope images of immobilized E. coli BL21(DE3) pET-bgl-hisactophilin-Sec cells in CeramTec PST 5: 1.5-2.5 mm (a, b, c) and 4-5 mm (d, e, f) after 24 h cultivation time.

the activity of free cells decreased after the first batch while that of the immobilized cells increased. High and stable enzyme production by immobilized cells in comparison to free cell culture was obtained in cycles from 3 to 5 days (144) and activity was almost 1.3 times higher than that of that of free cells $(500 \mathrm{U} / \mathrm{ml})$. This result was compatible with those reported by other researchers (Manolov, 1993; Petruccioli et al., 1994; Petruccioli et al., 1996), who concluded that the activity of free cells decreased after the first batch while that of the immobilized cells increased.

Scanning electron microscopy observations of immobilized E. coli cells. Fig. 4 shows an electron micrograph taken immediately after $24 \mathrm{~h}$ cultivation of immobilized
E. coli cells in CeramTec 1.5-2.5 mm (A) and CeramTec 4-5 mm (B). It is clear that a high number of cells also penetrated into the open pores within the beads and formed dense aggregates. Comparison of the electron micrographs indicates that there are a much higher number of $E$. coli cells in CeramTec $(1.5-2.5 \mathrm{~mm})$ than in CeramTec (4-5 mm). Images showed the immobilized cells on the surface and in the pores of a bead particle after $24 \mathrm{~h}$ of cultivation. This shows the successful immobilization of $E$. coli on the studied matrices.

Conclusions. Of the three carriers assayed, the best for the immobilization for enzyme production and with adhered biomass on a laboratory scale are broken 
pumice stone and CeramTec. Broken pumice stone allows the immobilization of a large number of cells ( $4 \mathrm{~g}$ cells/l of carrier) in a short time $(24 \mathrm{~h})$. Moreover, it leads to a high enzyme activity $(550 \mathrm{U} / \mathrm{ml})$, which makes the overall yields higher. Furthermore, it is an inert material and is very cheap, thus making the process potentially suitable for industrial scale-up. However, because of the abrasion problem of the broken pumice stone, which could lead to a serious error in the obtained results, CeramTec will be the second choice for bacterial immobilization. Glucanase activity reached by immobilized cells under batch cultivation is $650 \mathrm{U} / \mathrm{ml}$ after $60 \mathrm{~h}$.

\section{Acknowledgements \\ Prof. Flaschel (University of Bielefeld, Fermentation Engineer- ing Dept.) is acknowledged for providing the Escherichia coli strain.}

\section{Literature}

Beshay U. and A. Moreira. 2003. Repeated batch production of alkaline protease by using porous sintered glass as carriers. Process Biochemistry. 38: 1463-1469.

Beshay U., H. El-Enshasy, I.M.K. Ismail, H. Moawad, E. Wojciechowska and S. Abd-El-Ghany. 2003. $\beta$-Glucanase production from genetically modified recombinant Escherichia coli: Effect of growth substrates and development of a culture medium in shake flasks and stirred tank bioreactor. Process Biochemistry 39: 307-313.

Beshay U. Ph.D. Thesis 1998. Continuous cultivation with immobilized Dictyostelium discoideum, Faculty of Technology, University of Bielefeld, Germany.

Borriss R., O. Olsen, K.K. Thomsen and D. Von Wettstein. 1989. Hybrid Bacillus endo-(1-3,1-4)- $\beta$-glucanases: Construction of recombinant genes and molecular properties of the gene product. Carlsberg Res. Commun. 54: 41-54.
Colagrande O., A. Silva and M.D. Fumi. 1994. Recent applications of biotechnology in wine production. Rev. Biotechnol. Progr. 10: 2-18. Fiedurek J. and J. Lobarzewski. 1990. Glucoamylase biosynthesis by cells of Aspergillus niger C58-III immobilized in sintered glass and pumice stones. Starch. 42:3 58-362.

Flaschel E., L. Poppenborg, R. Neitzel, G. Miksch and K. Friehs. 1998. Affinitaetstrennverfahahren zur Gewinnung Rekombinanter Protein. Biotech. 9:26-29.

Giberson R.T., R.S. Jr Demaree and R.W. Nordhausen. 1997. Four-hour processing of clinical/diagnostic specimens for electron microscopy using microwave technique. J. Vet. Diagn. Invest. 9: 61-7. Gusek T.A., M.T. Tyn and J.E. Kinsella. 1991. Immobilization of the serine protease from Thermomonospora fusca YX on porous glass. Biotechnol. Bioeng. 36: 411-416.

Hamdy M.K., K. Kim and C.A. Rudtke. 1990. Continuous ethanol production by yeast immobilized on to channeled alumina beads. Biomass. 21: 189-206.

Henry R. and C. Clim. 1964. Principles and Technics. Harper-Row. N. York, pp. 182.

Kourkoutas Y., A. Bekatorou, I.M. Banat, R. Marchant and A.A. Koutinas. 2004. Immobilization technologies and support materials suitable in alcohol beverages production: a review. Food Microbiol. 21: 377-397.

Manolov R.J. 1993. Ribonuclease production by free and immobilized Aspergillus clavatus cells. World J. Microbiol. Biotechnol. 9: 29-33. Miksch G., R. Neitzel, E. Fiedler, K. Friehs and E. Flaschel. 1997. Extracellular production of a hybrid $\beta$-glucanase from Bacillus by Escherichia coli under different cultivation conditions in shaking cultures and bioreactors. Appl. Microbiol. Biotechnol. 47: 120-126. Petruccioli M., P. Piccioni, M. Fenice and F. Federici. 1994. Glucose oxidase, catalase and gluconic acid production by immobilized mycelium of Penicillium variable P16. Biotechnol. Lett. 16: 939-942. Petruccioli M., E. Angiani and F. Federici. 1996. Semi-continuous Fumaric acid production by Rhizopus arrhizus immobilized in polyurethane sponge. Proc. Biochem. 31: 463-469.

Weuster-Botz D. 1993. Continuous ethanol production by Xoutomonas mobilis in a fluidized bed reactor. Part I. Kinetic studies of immobilization in macroporus glass beads. Appl. Microbial. Biotechnol. 39:679-684. 